\title{
Kemampuan Pemodelan Matematika Siswa Dengan Strategi Scaffolding With A Solution Plan Pada Materi Trigonometri Di Kelas X SMAN 2 Palembang
}

\author{
Ardi Nuryadi $^{1^{*}}$, Budi Santoso ${ }^{2}$, Indaryanti $^{3}$ \\ 1,2,3 Universitas Sriwijaya, Kota Palembang, Sumatera Selatan 30128, Indonesia \\ Pengiriman: 25 Juli 2018; Diterima: 29 September 2018; Publikasi: 30 September 2018 \\ DOI: https://doi.org/10.31629/jg.v3i2.468
}

\begin{abstract}
Abstrak
Penelitian ini bertujuan untuk mendeskripsikan kemampuan pemodelan matematika siswa setelah diterapkannya pembelajaran dengan strategi scaffolding with a solution plan. Penelitian ini merupakan jenis penelitian deskriptif kuantitatif dengan subjek penelitian siswa kelas X IPS 2 SMAN 2 Palembang yang berjumlah 28 siswa. Teknik pengumpulan data dilakukan dengan tes tertulis yang terdiri atas empat soal uraian untuk mengukur kemampuan pemodelan matematika siswa. Soal tes disusun dengan mengacu pada indikator kemampuan pemodelan matematika. Berdasarkan hasil penelitian didapatkan bahwa kemampuan pemodelan matematika siswa kelas $\mathrm{X}$ IPS 2 SMAN 2 Palembang berada pada kategori baik dengan rincian sebagai berikut: 9 siswa berkategori sangat baik; 11 siswa berkategori baik; 5 siswa berkategori cukup; 2 siswa berkategori kurang; dan 1 siswa berkategori sangat kurang.
\end{abstract}

Kata kunci: kemampuan pemodelan matematika; scaffolding with a solution plan

\begin{abstract}
This study aims to describe the ability of students' mathematical modeling after the implementation of learning with a scaffolding with a solution plan strategy. Type of the research is quantitative descriptive research with research subjects of class X IPS 2 of SMAN 2 Palembang totaling 28 students. Data collection techniques were carried out with a written test consisting of four description questions to measure students' mathematical modeling abilities. Test questions were prepared by referring to indicators of mathematical modeling abilities. Based on the results of the study, it was found that the mathematical modeling ability of class X IPS 2 of SMAN 2 Palembang was in a good category with following details: 9 students are in very good category; 11 students are in good category; 5 students are in enough category; 2 students are in low category; 1 student is in very low category.
\end{abstract}

Keywords: mathematical modeling ability; scaffolding with a solution plan

\section{Pendahuluan}

Berdasarkan Peraturan Menteri

Pendidikan dan Kebudayaan No. 22 Tahun 2016 tentang standar proses bahwa salah satu prinsip pembelajaran pada kurikulum 2013 adalah

*Penulis Korespondensi

Email Address: ardynuryadi@gmail.com

Handphone : : +62 81329812456 merubah pembelajaran dari verbalisme menuju keterampilan aplikatif (Kemendikbud, 2016). Selain itu tuntutan dalam pembelajaran matematika adalah siswa dapat menyelesaikan masalah nyata dalam matematika. Hal itu 


\section{JURNAL GANTANG. September 2018; III(2): 73 - 81 \\ p-ISSN. 2503-0671 \\ e-ISSN. 2548-5547}

terdapat dalam tes PISA oleh OECD yang mana framework dari soal PISA adalah mathematical Literacy.

Pada literasi matematika siswa diharapkan untuk dapat menerapkan apa yang di peroleh dari sekolah dan diterapkan dalam kehidupan sehari-hari dalam berbagai situasi (OECD, 2013). Pentingnya menghubungkan matematika dengan kehidupan sehari-hari menurut Febrian (2016) adalah untuk mengubah paradigma yang menyatakan bahwa pengetahuan siswa yang didapat disekolah dan pengalaman sehari-hari siswa tidak memiliki koneksi. Berdasarkan tuntutan dalam pembelajaran matematika tersebut dapat disimpulkan bagaimana pentingnya kemampuan siswa dalam menerapkan pengetahuan yang didapat disekolah ke dalam masalah nyata.

Namun pada kenyataannya hasil penilaian PISA 2015 menunjukkan siswa Indonesia hanya mendapatkan 386 poin dan menempati peringkat 64 dari 72 negara yang mengikuti (OECD, 2016). Hal ini menunjukan bahwa terdapat masalah pada siswa dalam menyelesaikan soal PISA yang menggunakan konteks nyata. Hal tersebut juga ditunjukkan dalam beberapa penelitian (Murtiyasa, 2015; Puspitasari, dkk 2015; Qurota'yun, 2016) yang mengemukakan bahwa kelemahan siswa saat ini yaitu tidak dapat menghubungkan konsep-konsep matematika disekolah dengan pengalaman mereka sehari-hari dan juga siswa mengalami kesalahan transformasi atau siswa tidak dapat menerjemahkan soal dari bentuk nyata ke dalam model matematika.

Menurut Ang (2001) proses mengubah atau mewakili masalah dalam dunia nyata kedalam bentuk matematika dalam upaya untuk menemukan solusi dari suatu masalah disebut dengan pemodelan matematika. Kemudian menurut Maßß (2006) kompetensi dalam pemodelan mencakup keterampilan dan kemampuan untuk melakukan proses pemodelan secara tepat dan berorientasi pada tujuan. Yang selanjutnya kompetensi pemodelan tersebut dirumuskan menjadi beberapa indikator oleh Maаß (2006) yang kemudian digunakan dalam penelitian ini yaitu (1) memahami masalah sebenarnya, (2) menyiapkan model matematika dari model nyata, (3) menyelesaikan soal matematika dalam model matematika dan (4) menafsirkan hasil matematika dalam situasi nyata.

Salah satu materi yang menuntut siswa untuk dapat memecahkan masalah nyata yaitu trigonometri karena kompetensi yang harus dicapai sesuai dengan kurikulum adalah menyelesaikan masalah yang berkaitan dengan aturan sinus dan cosinus. Hal tersebut sejalan dengan kemampuan pemodelan yaitu untuk menyelesaikan masalah nyata. Selain itu materi trigonometri ini sangat penting karena menjadi materi pendahulu untuk pelajaran selanjutnya seperti integral, limit dan dimensi tiga.

Akan tetapi berdasarkan hasil penelitian Rumasoreng dan Sugiman (2014) didapatkan bahwa siswa tidak mampu dalam hal keterampilan menyelesaikan soal setara UN yang memuat materi trigonometri. Hal tersebut juga ditunjukan oleh Haryani (2012) dalam penelitian pendahuluan yang menemukan bahwa nilai rata-rata siswa pada materi trigonometri hanya 45.

Untuk mengatasi masalah tersebut Greefrath dan Leuders menyarankan dengan memberikan bantuan dalam membelajarkan pemodelan yaitu dengan strategi scaffolding karena berdasarkan penelitiannya menyimpulkan bahwa solusi akhir siswa dalam menyelesaikan masalah di pengaruhi oleh scaffolding yang diberikan (Stillman, Blum, \& Biembengut, 2015). Schukajlow, Kolter dan Blum (2015) manyatakan bahwa pemodelan matematika bukan hal yang mudah terutama untuk peserta didik yang baru mulai belajar pemodelan dan untuk mengontrol proses kerja mereka dibutuhkanlah bantuan untuk mengurangi kompleksitas yang dapat dipahami oleh siswa, model yang disederhanakan yang menggabungkan langkah-langkah tertentu dan bantuan itu disebut dengan scaffolding with a solution plan.

Scaffolding menurut Vygotsky (1978) berarti memberikan kepada seorang anak 
sejumlah besar bantuan selama tahap awal pembelajaran dan kemudian mengurangi bantuan tersebut dan memberikan kesempatan kepada anak mengambil alih tanggung jawab yang semakin besar setelah mampu mengerjakan sendiri. Sedangkan solution plan merupakan pemberian bantuan yang dapat diletakan di lembar kerja siswa (LKS) sehingga ketika siswa mengalami kesulitan guru sudah siap mengantisipasinya dengan memberikan bantuan berupa petunjuk dalam solution plan tersebut, sehingga siswa dapat bekerja dengan baik dan juga dapat mengetahui dimana fase mereka tidak membutuhkan bantuan kembali dalam menemukan solusi pemodelan matematika (Schukajlow et al., 2015).

Penggunaan LKS dalam membelajarkan pemodelan juga pernah dilakukan pada penelitian sebelumnya yaitu oleh Wulandari, Darmawijoyo dan Hartono (2016) yang mana hasilnya efektif dalam meningkatkan kemampuan siswa dalam mengubah masalah sehari-hari kedalam bentuk matematika, lalu mengaitkan topik matematika didalam soal untuk kemudian membuat persamaan dan mencari solusinya.

Berdasarkan uraian diatas, peran strategi scaffolding with a solution plan untuk kemampuan pemodelan matematika yaitu sebagai jembatan yang digunakan untuk menghubungkan apa yang sudah diketahui siswa dengan sesuatu yang baru atau yang akan diketahui siswa. Scaffolding merupakan upaya guru memberikan siswa tangga yang dapat membantu mereka mencapai kemampuan yang lebih tinggi, namun tentu diharapkan agar siswa sendiri yang memanjat tangga tersebut.

Berkaitan dengan hal tersebut diperlukan adanya peninjauan empiris mengenai dampak penggunaan scaffolding with a solution plan sebagai sebuah strategi pembelajaran, khususnya pada materi trigonometri terhadap kemampuan pemodelan matematika yang telah dilaksanakan melalui penelitian. Akhirnya, penelitian ini mendeskripsikan kemampuan pemodelan matematika siswa setelah diterapkannya pembelajaran dengan strategi scaffolding with a solution plan pada materi trigonometri.

\section{Metode Penelitian}

Penelitian ini merupakan penelitian deskriptif kuantitatif. Penelitian ini bertujuan untuk mendeskripsikan kemampuan pemodelan matematika siswa setelah diterapkan pembelajaran dengan strategi scaffolding with a solution plan pada materi trigonometri. Subjek dalam penelitian ini adalah siswa kelas X IPS 2 SMA Negeri 2 Palembang yang berjumlah 28 siswa

Variabel dalam penelitian ini adalah kemampuan pemodelan matematika siswa pada materi trigonometri. Kemampuan pemodelan matematika dalam penelitian ini adalah kecakapan siswa dalam menyelesaikan soal mengenai permasalahan nyata hingga memperoleh solusi dari masalah nyata tersebut. Yang mana kemampuan pemodelan matematika diukur melalui tes bentuk uraian dan penskorannya mengacu pada 4 indikator kemampuan pemodelan matematika yang dibuat oleh Maaß (2006) yaitu memahami masalah sebenarnya, menyiapkan model matematika, menyelesaikan soal dengan model matematika, menafsirkan solusi.

Penelitian ini terdiri atas tiga tahapan, yaitu tahap persiapan, tahap pelaksanaan kegiatan, dan tahap pengumpulan data. Pada tahap persiapan peneliti memvalidasi instrumen penelitian yang terdiri dari Rencana Pelaksanaan Pembelajaran (RPP), Lembar Kerja Peserta Didik (LKPD) serta soal tes, dimana validasi dilakukan dengan salah satu dosen pendidikan matematika dan juga dengan salah satu guru matematika. Setelah itu instrumen yang telah di validasi diujicobakan kepada siswa yang bukan merupakan subjek penelitian sehingga didapatlah instrumen yang telah melalui proses validasi. Gambar 1 adalah salah satu soal dalam instrumen tes kemampuan pemodelan matematika yang telah melalui proses validasi.

Pada tahap pelaksanaan pembelajaran, strategi scaffolding with a solution plan dilakukan dimana dalam pelaksanaannya diawali dengan memberikan masalah nyata. Kemudian dalam menyelesaikan masalah nyata tersebut di berikan bantuan sesuai dengan strategi scaffolding with a solution plan yang terdiri dari 


\section{JURNAL GANTANG. September 2018; III(2): 73 - 81 \\ p-ISSN. 2503-0671 \\ e-ISSN. 2548-5547}

empat langkah yaitu, understanding task, searching mathematics, using mathematics dan explaining results. Selanjutnya data dikumpulkan melalui tes tertulis. Tes yang diberikan merupakan tes tertulis bentuk uraian. Tes ini terdiri dari empat buah soal yang harus dijawab siswa mengenai kompetensi dasar dan indikator kemampuan pemodelan matematika siswa terkait materi aturan sinus dan cosinus. Tes ini dikerjakan siswa secara individu.

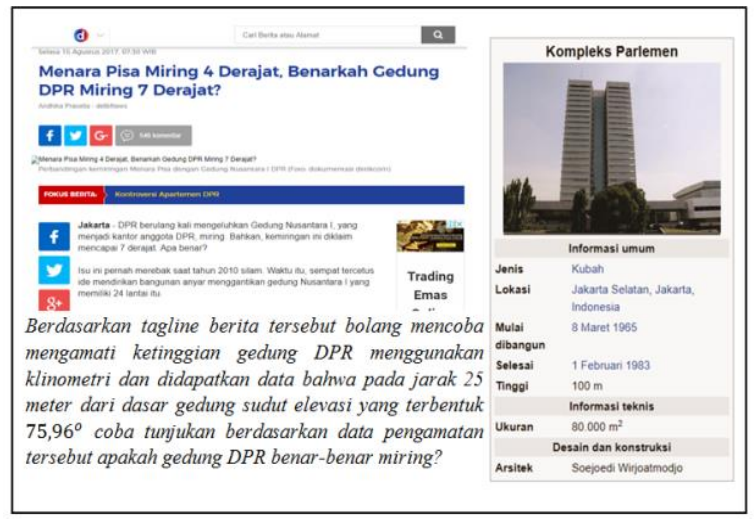

Gambar 1. Soal kemampuan pemodelan matematika

Setelah tes dilaksanakan, maka didapatkan skor masing-masing siswa. Skor dijumlahkan, kemudian dianalisis. Langkah untuk menganalisis data hasil tes tertulis adalah menentukan nilai tes siswa dan menentukan kategori kemampuan pemodelan matematika siswa.

Tabel 1.

Kategori kemampuan pemodelan matematika siswa

\begin{tabular}{cc}
\hline Rentang Nilai Siswa & $\begin{array}{c}\text { Kategori Kemampuan } \\
\text { Pemodelan }\end{array}$ \\
\hline $\mathbf{8 0} \leq \boldsymbol{T} \leq \mathbf{1 0 0}$ & Sangat Baik \\
\hline $\mathbf{6 0} \leq \boldsymbol{T}<\mathbf{8 0}$ & Baik \\
\hline $\mathbf{4 0} \leq \boldsymbol{T}<\mathbf{6 0}$ & Cukup \\
\hline $\mathbf{2 0} \leq \boldsymbol{T}<\mathbf{4 0}$ & Kurang \\
\hline $\mathbf{0} \leq \boldsymbol{T}<\mathbf{2 0}$ & Sangat Kurang \\
\hline
\end{tabular}

\section{Hasil dan Pembahasan}

Penelitian ini dilaksanakan di kelas $\mathrm{X}$ IPS 2 SMA Negeri 2 Palembang. Penelitian dilaksanakan sebanyak 3 pertemuan (6 jam pelajaran) dengan rincian dua pertemuan untuk kegiatan pembelajaran dan satu pertemuan terakhir untuk tes kemampuan pemodelan matematika. Dalam pelaksanaan pembelajaran sesuai dengan strategi scaffolding with a solution plan yaitu diberikan beberapa bantuan yang terdiri dari empat langkah yaitu, understanding task, searching mathematics, using mathematics dan explaining results.

Data mengenai kemampuan pemodelan matematika siswa diperoleh dari hasil tes dengan menggunakan tipe soal yang mengacu pada 4 indikator kemampuan pemodelan matematika. Tes dilaksanakan pada pertemuan ketiga atau pertemuan terakhir. Soal tes yang diberikan berupa soal bentuk uraian yang terdiri dari 4 soal yang dikerjakan siswa secara individu. Penskoran yang dilakukan sesuai dengan rubrik penskoran yang telah dibuat. Skor maksimal untuk masing-masing soal 13.

Setelah semua jawaban siswa diperiksa dan diberikan skor sesuai rubrik penskoran, selanjutnya dijumlahkanlah skor yang diperoleh dari keempat soal tersebut, kemudian dibagi dengan skor maksimal, yaitu 13 , selanjutnya dikalikan 100. Setelah diperoleh nilai siswa, nilai tersebut dikelompokkan ke dalam lima kategori kemampuan pemodelan matematika siswa dan dihitung rata-rata nilai siswa yang dapat dilihat pada tabel 2 .

Tabel 2.

Dist. frekuensi kemampuan pemodelan matematika

\begin{tabular}{cccc}
\hline Nilai & Kategori & Frekuensi & Persentase \\
\hline $80,0-100$ & $\begin{array}{c}\text { Sangat } \\
\text { Baik }\end{array}$ & 9 & $32 \%$ \\
\hline $60,0-79,9$ & Baik & 11 & $39 \%$ \\
\hline $40,0-59,9$ & Cukup & 5 & $18 \%$ \\
\hline $20,0-39,9$ & Kurang & 2 & $7 \%$ \\
\hline $0-19,9$ & $\begin{array}{c}\text { Sangat } \\
\text { Kurang }\end{array}$ & 1 & $4 \%$ \\
\hline Rata-rata & Baik & $\mathbf{6 7 , 8 5}$ & \\
\hline
\end{tabular}

Dari tabel 2 dapat dilihat bahwa secara statistika rata-rata kemampuan pemodelan matematika siswa kelas X IPS 2 SMAN 2 Palembang mendapat niali 67,85 dan berkategori baik.

Penelitian tentang kemampuan pemodelan matematika dengan strategi scaffolding with a solution plan pada materi trigonometri mempunyai tujuan untuk memperoleh gambaran tentang kemampuan 
pemodelan matematika siswa di kelas X IPS 2 SMA Negeri 2 Palembang yang ditunjukkan melalui soal tes yang diberikan. Pembelajaran dalam penelitian ini menggunakan LKS yang merupakan wujud dari strategi scaffolding with a solution plan yang mana LKS dibuat berdasarkan tahapan-tahapan strategi scaffolding with a solution plan yaitu: tahap understanding task, tahap searching mathematics, tahap using mathematics, dan tahap explaining results.

Saat pembelajaran pada tahap understanding task siswa diberikan permasalahan nyata mengenai aturan sinus dan cosinus kemudian siswa diminta untuk mengidentifikasi masalah dan membayangkan bagamaina situasi dari masalah tersebut dan membentuk sketsa dari apa yang mereka bayangkan. Kemudian pada tahap searching mathematics siswa diminta untuk menghubungkan masalah yang terjadi dari apa yang disketsakan dengan masalah matematika dengan cara menyederhanakan hal-hal yang diketahui dan ditanyakan dan juga menemukan unsur-unsur yang dibutuhkan serta menambahkan variabel hingga terbentuk model matematika. Pada tahap using mathematics siswa diminta untuk menggunakan konsep matematika yang dapat digunakan berdasarkan model matematika yang didapatkan dalam hal ini siswa diarahkan untuk menggunakan aturan sinus ataupun aturan cosinus. Pada tahap explaining results siswa diminta untuk menerapkan hasil yang didapat secara matematika kedalam masalah nyata. Kemudian siswa diminta untuk mengecek kembali solusi yang didapatkan sesuai dengan arahan bantuan yang telah disediakan.

Setelah siswa selesai dalam memecahkan masalah yang terdapat di LKS perwakilan kelompok memaparkan apa yang didapat dari diskusi kelompok didepan kelas yang kemudian secara bersama-sama menyimpulkan pengetahuan baru yang dipelajari dalam memecahkan masalah nyata. Dengan begitu secara tidak langsung siswa telah menggunakan kemampuan pemodelan matematika dalam menyelesaikan LKS tersebut.

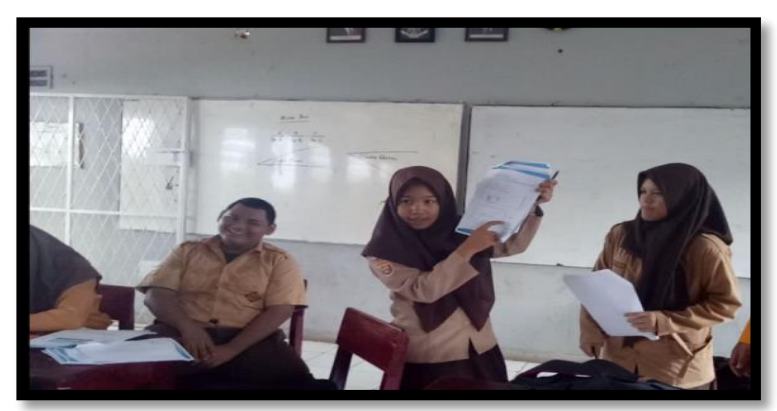

Gambar 2. Perwakilan kelompok memaparkan hasil diskusi.

Berikut disajikan beberapa contoh jawaban siswa pada masing-masing kategori.

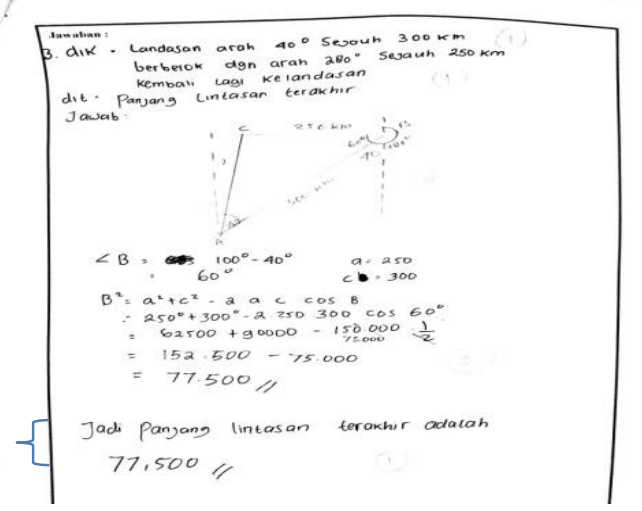

Gambar 3. Jawaban siswa MAP kategori sangat baik.

Pada gambar 3 diatas siswa sudah mampu memenuhi semua indikator pemodelan hanya saja pada indikator menyelesaikan soal dengan model matematika siswa kurang teliti padahal 77.500 tersebut merupakan nilai $a^{2}$ bukan nilai $a$, akan tetapi siswa melewatkannya sehingga solusi yang diperoleh kurang tepat dikarenakan perhitungan yang tidak lengkap pada indikator menyelesaikan soal dengan model matematika sehingga dalam menafsirkan solusi yang diperoleh juga kurang tepat meskipun sebenarnya siswa sudah mengerti langkahlangkah yang harus diselesaikan dalam menyelesaikan soal pemodelan. Hal tersebut dikarenakan adanya peran scaffolding dalam pembelajaran sebelumnya yang membagi menjadi 4 langkah dalam menyelesaikan masalah pemodelan dimana hal tersebut sesuai dengan karakteristik scaffolding menurut McKenzie dalam Van Der Stuyf (2002) yaitu menyajikan rincian dengan jelas dan mengurangi kebingungan peserta didik yaitu pendidik mengantisipasi masalah-masalah yang 


\section{JURNAL GANTANG. September 2018; III(2): 73 - 81 \\ p-ISSN. 2503-0671 \\ e-ISSN. 2548-5547}

kemungkinan dihadapi peserta didik dan kemudian memberikan petunjuk langkah demi langkah yang harus dilakukan peserta didik untuk memenuhi harapannya. Dari jawaban tersebut juga dapat dilihat jawaban siswa dalam membuat model matematika dengan menggambarkan langsung modelnya serta mengidentifikasi variabel yang dibutuhkan dari satu gambar tersebut padahal ketika pembelajaran scaffolding yang diberikan untuk menemukan model matematika melalui dua gambar, yang pertama gambar mengenai permasalahan nyata yang mereka bayangkan dan gambar yang kedua merupakan model matematika dengan variabelnya. Hal itu tidak terlepas dari peran upaya guru memberikan siswa tangga yang dapat membantu mereka mencapai kemampuan yang lebih tinggi, namun siswa memanjat tangga tersebut dengan caranya sendiri.

Kemudian siswa dengan kategori baik yang berjumlah 11 orang atau 39\% juga sudah mampu menyelesaikan masalah pemodelan, akan tetapi masalah yang dialami tidak berbeda jauh dengan siswa pada kategori sangat baik yaitu kurangnya ketelitian sehingga terdapat proses yang tertinggal. Berikut contoh jawaban No.1 siswa LW yang termasuk dalam dalam kategori baik.

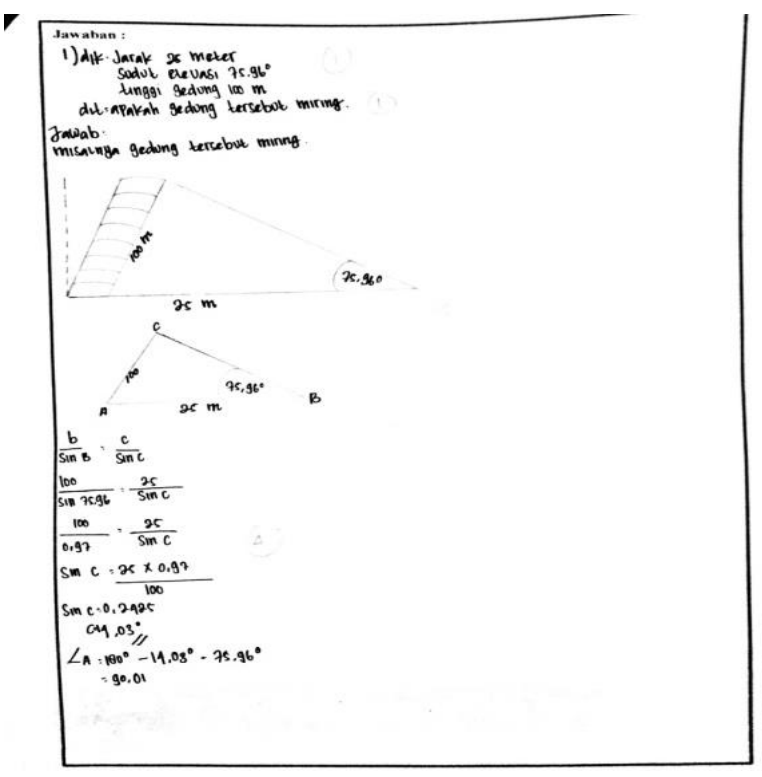

Gambar 4. Jawaban siswa LW kategori baik.

Pada gambar 4 siswa sudah mampu memenuhi beberapa indikator pemodelan. Pada indikator memahami masalah sebenarnya siswa tidak mengubah apa yang diketahui dan ditanyakan kedalam variabel-variabel akan tetapi siswa langsung memasukan nilainya kedalam sketsa yang telah dibuatnya. Kemudian pada indikator menafsirkan solusi siswa tidak mengintepretasi solusi yang didapat secara matematika kedalam masalah nyata sehingga siswa hanya memperoleh skor 10 dari total skor 13.

Pada jawaban siswa tersebut dapat dilihat cara siswa dalam menyelesaikan soal pemodelan dimana siswa dalam membuat model matematika terlebih dahulu membuat sketsa berdasarkan permasalah nyata kemudian setelah itu mensketsakan ulang dengan menambahkan variabel-variabel yang mana cara tersebut merupakan bantuan yang diberikan pada tahap pembelajaran dengan scaffolding with a solution plan yaitu pada tahap understanding task dan searching mathematics. Hal tersebut sesuai dengan hasil penelitian Stillman et al. (2015) yang menyimpulkan bahwa solusi akhir siswa dalam menyelesaikan masalah di pengaruhi dengan scaffolding yang diberikan. Selain itu pendapat Schukajlow et al. (2015) juga menyatakan bahwa penggunaan scaffolding with a solution plan berguna untuk mengarahkan cara kerja siswa dalam menyelesaikan masalah pemodelan.

Kemudian siswa dalam kategori kurang dan sangat kurang terlihat bahwa siswa tidak mampu dalam menyelesaikan soal pemodelan dimana siswa dalam katgori kurang dan sangat kurang hanya mampu pada indikator mengidentifikasi masalah sebenarnya. Jawaban siswa Subyek MI untuk soal nomor 2 yang merupakan siswa kategori kurang disajukan pada gambar 5.

Pada gambar 5 tersebut siswa mampu mengidentifikasi masalah yang terjadi didalam soal akan tetapi siswa tidak mengubah unsur yang diketahui dan ditanyakan tersebut kedalam bentuk variabel, kemudian siswa mulai membentuk model dengan cara mensketsakan situasi permasalahan akan tetapi siswa tidak 
menggunakan variabel-variabel sehingga terlihat bahwa siswa mengalami kesulitan dalam membentuk model matematika.

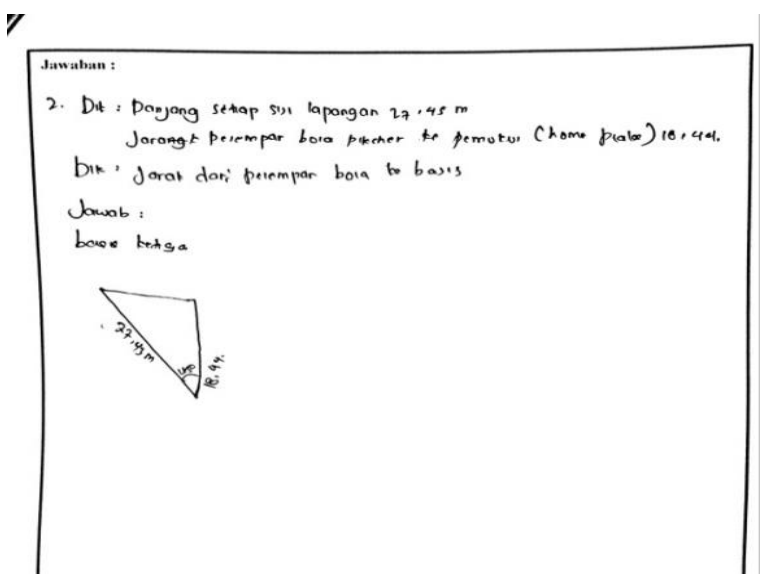

Gambar 5. Jawaban siswa MI kategori kurang

Menurut Crouch dan Haines dalam Parlaungan (2008) mengatakan salah satu aspek kesulitan siswa membuat pemodelan adalah interfase diantara masalah dunia real dan model matematika. Kesulitan tersebut diakibatkan karena ketika tes tidak diberikannya bantuan yang mana menurut Hartman dalam Sutiarso (2009) kelemahan strategi scaffolding salah satunya adalah siswa terkadang kurang percaya diri menyelesaikan tugas-tugasnya bila bantuan dikurangi/dihilangkan. Kesalahan lain yang dialami siswa pada kategori kurang dan sangat kurang adalah siswa tidak mampu dalam menggambarkan situasi permalahan yang mana penyebabnya dikarenakan siswa tidak memahami soal sehingga siswa sulit membuat model matematika (Puspitasari, dkk 2015).

Selanjutnya dari hasil analisis tes pada didapatkan kemampuan pemodelan matematika siswa kelas X IPS 2 SMAN 2 Palembang berada pada kategori sangat baik dan baik sebanyak $71 \%$ hal ini dikarenakan pembelajaran dengan strategi scaffolding memiliki karakteristik menyajikan rincian dengan jelas dan mengurangi kebingungan peserta didik yaitu pendidik mengantisipasi masalah-masalah yang kemungkinan dihadapi peserta didik dan kemudian memberikan petunjuk langkah demi langkah yang harus dilakukan peserta didik untuk memenuhi harapannya (Van Der Stuyf, 2002). Sehingga dapat dilihat bahwa siswa dalam melakukan pengerjaan soal pemodelan sudah teratur dan mengerti langkah-langkah apa saja yang harus dikerjakan.

Kemudian peran scaffolding with a solution plan dalam jawaban siswa juga terlihat pada bagian ketika siswa menerjemahkan masalah nyata kedalam bentuk matematika. Dalam hal ini siswa menjawab soal tes terlihat beberapa dari mereka mulanya mensketsakan masalah nyata kemudian membentuk model matematika. Hal itu merupakan bagian dari strategi scaffolding with a solution plan pada tahap understanding task dan searching mathematics dimana pada tahap understanding task siswa mulai membayangkan masalah sebenarnya dengan mensketsakan kemudian pada tahap searching mathematics siswa membentuk model matematika dengan menambahkan variabel-variabel. Dan hal tersebut sejalan dengan hasil penelitian Stillman et al., (2015:8) yang menyimpulkan bahwa solusi akhir siswa dalam menyelesaikan masalah di pengaruhi dengan scaffolding yang diberikan.

\section{Kesimpulan}

Berdasarkan hasil penelitian di kelas X IPS 2 SMAN 2 Palembang dapat disimpulkan bahwa kemampuan pemodelan matematika siswa dengan strategi scaffolding with a solution plan berkategori baik dengan rincian $32 \%$ siswa berkategori sangat baik, 39\% siswa berkategori baik, 18\% siswa berkategori cukup, 7\% berkategori kurang, dan $4 \%$ siswa berkategori sangat kurang dan nilai rata-rata siswa 67,85.

Strategi scaffolding with a solution plan membantu siswa dalam menyelesaikan soal pemodelan matematika terutama pada tahap understanding task dan juga searching mathematics. Dimana pada tahap understanding task siswa membayangkan situasi sebenarnya yang kemudian dituangkan dalam bentuk sketsa. Pada tahap searching mathematics siswa dilatih untuk menyusun model matematika berdasarkan apa yang sudah disketsakan oleh siswa. Dari hasil penelitian tersebut maka disarankan terutama dalam mengajarkan materi yang berkaitan dengan pemodelan hendaknya menyediakan bantuan dengan menggunakan strategi scaffolding with a solution plan. 


\section{JURNAL GANTANG. September 2018; III(2): 73 - 81 \\ p-ISSN. 2503-0671 \\ e-ISSN. 2548-5547}

\section{Ucapan Terimakasih}

Penulis menyampaikan terima kasih kepada seluruh pihak yang memberikan dukungan, Cecil Hiltrimartin, M.Si., Ph.D., selaku Ketua Program Studi Pendidikan Matematika. Scristia, S.Pd., M.Pd. \& Edi Sumarno, S.Pd selaku validator dan rekan-rekan Pendidikan Matematika FKIP Universitas Sriwijaya angkatan 2014.

\section{Referensi}

Ang, K. C. (2001). Teaching mathematical modelling in Singapore schools. The Mathematics Educator, 6(1), 63-75. Retrieved from https://repository.nie.edu.sg/handle/10497/4 9

Febrian. (2016). The instruction to overcome the inert knowledge issue in solving mathematical problem. Jurnal Gantang, $1(1), 15-22$.

Haryani, F. (2012). Meningkatkan motivasi dan pemahaman konsep perbandingan fungsi trigonometri melalui model pembelajaran jigsaw di SMA Negeri 8 Kota Jambi. EduSains, 1(1), 34-37.

Kemendikbud. (2016). Peraturan Menteri Pendidikan dan Kebudayaan Nomor 22 Tahun 2016 tentang Standar Proses Pendidikan Dasar dan Menengah, Menteri Pendidikan dan Kebudayaan.

Maaß, K. (2006). What are modelling competencies? ZDM - International Journal on Mathematics Education, 38(2), 113-142. https://doi.org/10.1007/BF02655885

Murtiyasa, B. (2015). Tantangan pembelajaran matematika era global (pp. 28-47). Surakarta: Muhammadiyah University Press.

OECD. (2013). PISA 2015 Draft Mathematics Framework. Retrieved from https://www.oecd.org/pisa/pisaproducts/Dr aft PISA 2015 Mathematics Framework .pdf

OECD. (2016). PISA Results 2015. Retrieved from https://www.oecd.org/pisa/PISA2015-Indonesia.pdf
Parlaungan. (2008). Pemodelan matematika untuk meningkatkan bermatematika siswa sekolah menengah atas. Universitas Sumatera Utara. Retrieved from http://repository.usu.ac.id/handle/12345678 9/6060?show=full

Puspitasari, E., Y, E., \& N, A. (2015). Analisis kesulitan siswa menyelesaikan soal cerita materi sistem persamaan linier dua variabel. Jurnal Pendidikan Dan Pembelajaran, 4(5), 1-9.

Qurota'yun, U. N. (2016). Analisis kesalahan siswa dalam menyelesaikan soal cerita persamaan linier sau variabel. Universitas Muhammadiyah Surakarta. Retrieved from http://eprints.ums.ac.id/45083/1/02. naskah publikasi.pdf

Rumasoreng, M. I., \& Sugiman. (2014). Analisis kesulitan matematika siswa SMA/MA dalam menyelesaikan soal setara UN di Kabupaten Maluku Tengah. Jurnal Riset Pendidikan Matematika, 1(1), 22-34. https://doi.org/http://dx.doi.org/10.21831/jr pm.vli1.2661

Schukajlow, S., Kolter, J., \& Blum, W. (2015). Scaffolding mathematical modelling with a solution plan. ZDM - Mathematics Education, 47(7), 1241-1254. https://doi.org/10.1007/s11858-015-0707-2 Stillman, G. A., Blum, W., \& Biembengut, M. S. (2015). Learning of mathematical modelling mathematical modelling in education research and practice cultural, social and cognitive influences. Switzerland: Springer International Publishing Switzerland.

Sutiarso, S. (2009). Scaffolding dalam pembelajaran matematika. In Pendidikan dan Penerapan MIPA (pp. 527-530). Yogyakarta: Universitas Negeri Yogyakarta.

Van Der Stuyf, R. R. (2002). Scaffolding as a teaching strategy. Adolescent Learning and Development Journal. Retrieved from http://r2ed.unl.edu/CSI/dissemination/down loads/educator/unit_lesson_plans/inquiry_r ubrics_teaching_resources/resources/CSI_s 
caffolding_handout.pdf

Vygotsky, L. S. (1978). Mind in society: the

development of higher psychological

processes. full-text. (N.D.). London:

Harvard University press.

https://doi.org/10.1007/978-3-540-92784-6

Wulandari, W., Darmawijoyo, \& Hartono, Y. (2016). Pengaruh pendekatan pemodelan matematika terhadap kemampuan argumentasi siswa kelas VIII SMP Negeri 15 Palembang. Jurnal Pendidikan Matematika, 10(1). 
JURNAL GANTANG. September 2018; III(2): 73 - 81

p-ISSN. 2503-0671

e-ISSN. 2548-5547 